\title{
EKSPERIMEN PEMBELAJARAN MATEMATIKA BERBASIS REALISTIC MATHEMATICS EDUCATION TERHADAP HASIL BELAJAR DI TINJAU DARI KEMAMPUAN KOMUNIKASI MATEMATIKA SISWA KELAS VII SEMESTER GASAL SMP N 1 BAKI
}

\author{
Oleh: \\ Rizka Ni'matillah \\ Universitas Muhammadiyah Surakarta
}

\begin{abstract}
Abstrak
Hasil belajar itu penting untuk mengetahui kepahaman siswa setelah proses pembelajaran. Diperlukan pendekatan pembelajaran agar hasil belajar menjadi baik yaitu Realistic Mathematics Education. Selain itu, kemampuan komunikasi matematika juga berpengaruh terhadap hasil belajar. Penelitian ini bertujuan untuk mendiskripsikan dan menganalisis : (1) konstribusi pembelajaran matematika berbasis Realistic Mathematics Education terhadap hasil belajar, (2) konstribusi kemampuan komunikasi matematika siswa terhadap hasil belajar, (3) interaksi pembelajaran matematika berbasis Realistic Mathematics Education dan kemampuan komunikasi matematika siswa terhadap hasil belajar. Populasi dalam penelitian ini adalah siswa kelas VII SMP N 1 Baki tahun 2015/2016. Sampel dari penelitian ini dua kelas masing - masing terdiri 31 siswa. Kelas pertama sebagai kelas eksperimen menggunakan pembelajaran berbasis Realistic Mathematic Education dan kelas kedua sebagai kelas kontrol menggunakan pembelajaran ekspositori.

Teknik pengambilan sampel yang digunakan adalah simple random sampling.

Metode pengumpulan data yang digunakan adalah tes, angket, dan dokumentasi. Teknik analisis yang digunakan adalah analisis variansi dua jalan dan sebelumnya telah dilakukan uji normalitas dan uji homogenitas. Dari hasil penelitian pada $\alpha=0,05$ diperoleh : (1) terdapat konstribusi pembelajaran matematika berbasis Realistic Mathematics Education terhadap hasil belajar dengan $\mathrm{F}_{\mathrm{obs}}=5,573185>\mathrm{F}_{\alpha}=4,01$; (2) terdapat konstribusi kemampuan komunikasi matematika siswa terhadap hasil belajar dengan $\mathrm{F}_{\mathrm{obs}}=15,95437>$ $\mathrm{F}_{\alpha}=3,16$; (3) terdapat interaksi pembelajaran matematika berbasis Realistic Mathematics Education dan kemampuan komunikasi matematika siswa terhadap hasil belajar dengan $\mathrm{F}_{\mathrm{obs}}=3,445566>\mathrm{F}_{\alpha}=3,16$.
\end{abstract}

Kata Kunci: Hasil Belajar, Kemampuan Komunikasi Matematika, Realistic Mathematics Education

\section{Pendahuluan}

Hasil belajar diperlukan untuk mengetahui tercapainya kompetensi yang diberikan setelah dilakukan proses pembelajaran sebagai bentuk evaluasi dalam pendidikan. Menurut Heri Prianto (2013: 95) hasil belajar adalah "Kemampuan yang dimiliki siswa setelah ia menerima pengalaman belajarnya (dari tidak tahu menjadi tahu dan dari tidak mengerti menjadi mengerti)". Namun, pada realitanya hasil belajar tahun ini tidak memenuhi harapan. Berdasarkan data yang diperoleh, ada 28,51\% dari kelas VII SMP N 1BAKI yang 
berjumlah 256 siswa belum mencapai batas Kriteria Ketuntasan Minimal 70 (analisis dokumen daftar nilai ujian tengah semester gasal tahun 2015/2016 kelas VII). Faktor penyebab bervariasinya hasil belajar bisa bersumber dari siswa dan guru. Faktor yang bersumber dari siswa yaitu faktor yang berasal dari dalam diri siswa yang meliputi fisiologis dan psikologis. Pada faktor fisiologis, hasil belajar dipengaruhi oleh kesehatan dan catat tubuh yang dialami siswa sedangkan faktor psikologis, hasil belajar dipengaruhi oleh intelegensi,minat, bakat, kematangan dan kesiapan. Di lain pihak, faktor penyebab yang bersumber dari guru yaitu segala sesuatu yang menyangkut kepribadian guru dan kemampuan mengajarnya.

Permasalahan bervariasinya hasil belajar dapat dipengaruhi oleh pembelajaran matematika berbasis Realistic Mathematics Education dan kemampuan komunikasi matematika siswa. Realistic Mathematics Education yang dimaksud yaitu suatu pembelajaran matematika dimana masalah nyata yang dikenal, dialami dan dapat dibayangkan siswa menjadi titik awal pembelajaran sehingga berpengaruh pada hasil belajar. Kemampuan komunikasi matematika yang dimaksud yaitu kemampuan siswa dalam menghubungkan pesan berupa ide-ide pemecahan masalah, strategi maupun solusi matematika baik tertulis maupun lisan sehingga terjadi pengalihan pesan matematika yang dipelajarinya dan berdampak pada hasil belajar. Hal ini sesuai dengan tujuan mata pelajaran matematika yang dituangkan dalam Peraturan Menteri Pendidikan Nasional Nomor 22 Tahun 2006 tentang Standar Isi untuk Satuan Pendidikan Dasar dan Menengah sebagai berikut.

1. Memahami konsep matematika, menjelaskan keterkaitan antar konsep dan mengaplikasikan konsep atau logaritma secara luwes, akurat, efisien, dan tepat dalam pemecahan masalah.

2. Menggunakan penalaran pada pola dan sifat, melakukan manipulasi matematika dalam membuat generalisasi, menyusun bukti, atau menjelaskan gagasan dan pernyatan matematika.

3. Memecahkan masalah yang meliputi kemampuan memahami masalah, merancang model matematika, menyelesaikan model dan menafsirkan solusi yang diperoleh.

4. Mengkomunikasikan gagasan dengan simbol, tabel, diagram, atau media lain untuk memperjelas keadaan atau masalah.

5. Memiliki sikap menghargai kegunaan matematika dalam kehidupan, yaitu memiliki rasa ingin tahu, perhatian, dan minat dalam mempelajari matematika, serta sikap ulet dan percaya diri dalam pemecahan masalah (Depdiknas, 2006: 346). 
Berdasarkan uraian tersebut, dapat diberikan makna pembelajaran matematika berbasis Realistic Mathematics Education dan kemampuan komunikasi matematika berinteraksi terhadap hasil belajar siswa. Berdasarkan latar belakang dapat diajukan tiga masalah 1) Adakah konstribusi pembelajaran matematika berbasis Realistic Mathematics Education terhadap hasil belajar ? 2) Adakah konstribusi kemampuan komunikasi matematika siswa terhadap hasil belajar ? 3) Adakah interaksi pembelajaran matematika berbasis Realistic Mathematics Education dan kemampuan komunikasi matematika siswa terhadap hasil belajar?

\section{Landasan Teori}

1. Hasil Belajar

Menurut Heri Prianto (2013: 95) hasil belajar adalah "Kemampuan yang dimiliki siswa setelah ia menerima pengalaman belajarnya (dari tidak tahu menjadi tahu dan dari tidak mengerti menjadi mengerti)". Salamat Siregar (2013: 57) menambahkan bahwa hasil belajar adalah "Sekumpulan pengetahuan yang dimiliki oleh siswa setelah melalui proses pembelajaran". Berdasarkan pendapat ahli tersebut, hasil belajar merupakan kemampuan yang dimiliki siswa setelah melalui proses pembelajaran (dari tidak tahu menjadi tahu dan dari tidak mengerti menjadi mengerti). Kriteria ketuntasan minimal (KKM) di SMP N 1 Baki yaitu 70. Hasil belajar siswa dikatakan tuntas apabila nilai yang diperoleh siswa lebih dari atau sama dengan KKM.

\section{Realistic Mathematics Education}

a. Pengertian pembelajaran Realistic Mathematics Education

Realistic Mathematics Education adalah "A design theory for mathematics education proposed by Hans Freudenthal and developed over 40 years of developmental research at the Freudenthal Institute for Science and Mathematics Education in Netherlands (David C. Webb et al., 2011: 47)”. David C. Webb dkk (2011: 47) menambahkan prinsip penting dari RME adalah " Engagement in mathematics for students should begin within a meaningful context." Judah P. Makonye (2014: 655) mengemukakan bahwa Realistic Mathematics Education ialah pendekatan yang dapat mengatasi kesalahpahaman konsep matematika yang dialami siswa dengan cara mendorong matematika menjadi lebih relevan dan menarik sesuai kebutuhan siswa sehingga membuat matematika menjadi bermakna dan menyenangkan.

Pada penelitian ini, Realistic Mathematics Education merupakan suatu pendekatan pembelajaran matematika yang melibatkan konteks dunia nyata sehingga 
dapat mengatasi kesalahpahaman konsep matematika dan menjadi pengalaman pembelajaran yang bermakna bagi siswa. Penggunaan pembelajaran Realistic Mathematics Education diperlukan keaktifan siswa dalam belajar. Hal ini dikarenakan pembelajaran ini berpusat pada siswa. Guru memberikan masalah konstektual kepada siswa dan siswa diminta menyelesaikan masalah sedangkan guru hanya mengarahkan siswa pada jawaban dan kesimpulannya.

b. Langkah-langkah Realistic Mathematics Education

Menurut Murdani, Rahmah Johar dan Turmudi (2013: 26) terdapat 4 langkah dalam Realistic Mathematics Education.

1) Memahami masalah kontekstual

2) Menyelesaikan masalah kontekstual

3) Membandingkan dan mendiskusikan jawaban

4) Menyimpulkan

c. Keunggulan Realistic Mathematics Education

Menurut Nida Jarmita dan Hazami (2013: 216) terdapat beberapa keunggulan dari Realistic Mathematics Education.

1) Suasana dalam proses pembelajaran menyenangkan karena menggunakan realitas yang ada di sekitar siswa.

2) Siswa membangun sendiri pengetahuannya sehingga siswa tidak mudah melupakan materi yang diajarkan.

3) Siswa merasa dihargai dan semakin terbuka karena setiap jawaban ada nilainya.

4) Memupuk kerja sama dalam kelompok.

5) Melatih siswa untuk terbiasa berpikir dan berani mengemukakan pendapat.

6) Pendidikan budi pekerti, misalnya saling bekerja sama dan menghormati teman yang sedang berbicara

3. Ekspositori

a. Pengertian pembelajaran ekspositori

Siti Chotimah (2013: 330) mengemukakan bahwa ekspositori merupakan pendekatan dimana guru menyampaikan informasi bahan pembelajaran dalam bentuk penjelasan secara lisan kepada siswa dan diharapkan siswa menerima dan mengingat informasi tersebut. Dalam penelitian ini, pembelajaran ekspositori adalah pendekatan pembelajaran dimana guru berperan aktif dalam proses pembelajaran, guru menjelaskan pokok bahasan secara lisan dan diharapkan siswa dapat menerima serta memahami informasi yang diberikan. 
b. Langkah-langkah pembelajaran ekspositori

Menurut Lusia Ari Sumirat (2014: 25), langkah-langkah pendekatan ekspositori yaitu guru menjelaskan rumus dan dalil matematika terlebih dahulu, pemberian contoh, siswa bertanya, siswa berlatih soal yang diberikan kemudian guru memberikan penilaian dari hasil pekerjaan siswa.

c. Keunggulan pembelajaran ekspositori

Menurut Ali Syahbana (2012: 47), pendekatan ekspositori memiliki kelebihan yaitu melalui penanaman konsep secara langsung kepada siswa dengan memberikan jabaran dan keterangan yang jelas serta argumen yang tepat beserta contohnya, maka siswa dapat menerima materi dengan mudah tanpa bersusah payah mencari sendiri.

4. Kemampuan Komunikasi Matematika

Mila Miliatiningsih (2014: 353) mengatakan bahwa komunikasi matematik adalah cara menyampaikan ide-ide pemecahan masalah, strategi maupun solusi matematika baik secara tertulis maupun lisan. Pada penelitian ini, kemampuan komunikasi matematika adalah kecakapan siswa dalam menghubungkan pesan berupa ide-ide pemecahan masalah, strategi maupun solusi matematika baik tertulis maupun lisan sehingga terjadi pengalihan pesan matematika yang dipelajarinya. Dalam penelitian ini aspek kemampuan komunikasi matematika meliputi mendengar, membaca, diskusi dan menulis. Indikator-indikator dalam keempat aspek tersebut adalah sebagai berikut.

a. Indikator mendengar

1) Memberikan pendapat atau komentar terhadap suatu pernyataan yang diberikan

2) Mengkontruksi pengetahuan matematika dari suatu soal atau masalah

b. Indikator membaca.

1) Mengingat dan memahami apa yang terkandung dalam bacaan.

2) Membandingkan antar konsep matematika.

3) Menganalisis isi bacaan

c. Indikator diskusi

1) Mengungkapkan ide atau gagasan yang berkaitan dengan materi yang sedang dipelajari secara lisan.

2) Menanyakan permasalahan tentang materi yang sedang dipelajari

d. Menulis

1) Mengungkapkan pemahaman suatu materi atau permasalahan dalam media kertas atau media lainnya

2) Merefleksikan ide atau gagasan ke dalam media kertas maupun media lain 


\section{Kerangka Berpikir}

Kerangka pemikiran dalam penelitian ini dapat digambarkan sebagai berikut:

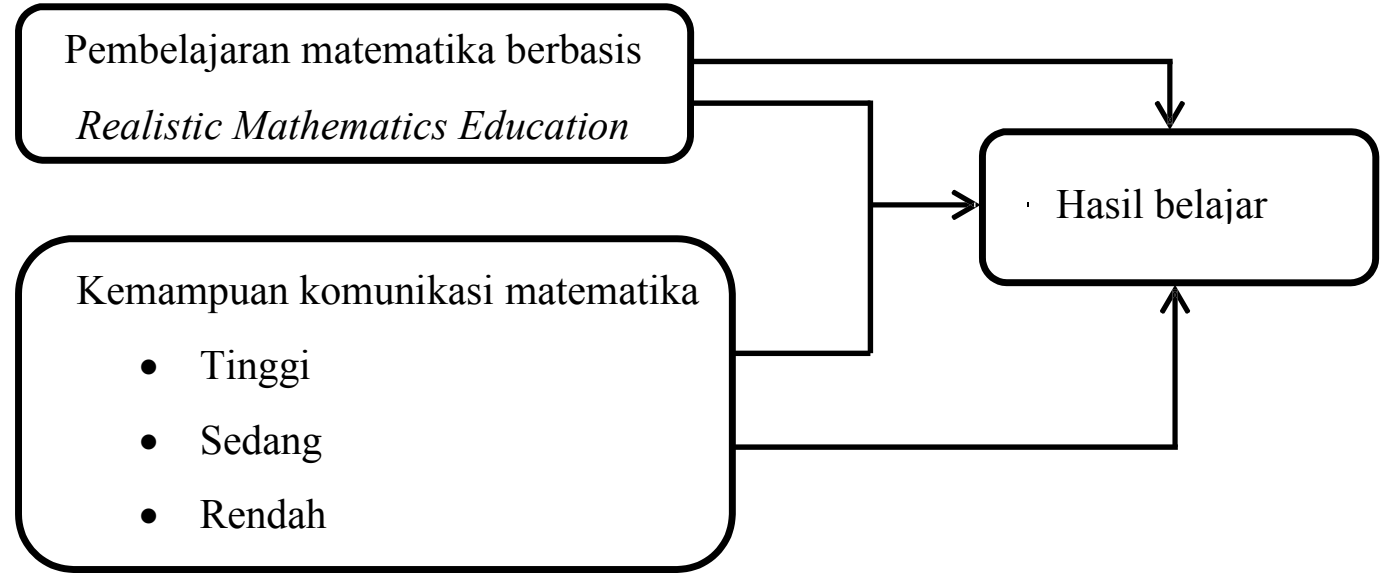

Gambar 1. Kerangka Berpikir dalam Penelitian

\section{Metode Penelitian}

A. Jenis dan Desain Penelitian

Jenis penelitian yang digunakan dalam penelitian ini adalah penelitian eksperimen. Menurut Sutama (2012: 53) penelitian eksperimen adalah penelitian yang berupaya untuk meneliti dan menemukan pengaruh variabel tertentu terhadap variabel lainnya dalam kondisi yang sengaja dikontrol. Pelaksanaan penelitian ini menggunakan dua kelas yaitu kelas eksperimen dan kelas kontrol. Pada kelas eksperimen pembelajaran dilakukan dengan menggunakan pembelajaran berbasis Realistic Mathematics Education sedangkan kelas kontrol menggunakan pembelajaran ekspositori. Pada tahap akhir penelitian, masingmasing kelas diberi tes untuk mengukur tingkat hasil belajar siswa dan diberikan angket untuk mengukur tingkat kemampuan komunikasi matematika pada siswa.

Desain penelitian dalam penelitian ini yaitu kuasi-eksperimental. Menurut Sutama (2012: 57) kuasi eksperimental adalah desain penelitian yang menyertakan kelompok kontrol, walaupun tidak dapat berfungsi untuk mengontrol variabel-variabel luar yang dapat mempengaruhi kelangsungan eksperimen.

B. Tempat dan Waktu Penelitian

Tempat penelitian dilaksanakan di SMP N 1 Baki Jalan Mawar Nomor 1 Kelurahan Kadilangu, Kecamatan Baki, Kabupaten Sukoharjo, Kode Pos 57665, telepon (0271) 625153. Pelaksanaan penelitian dilaksanakan pada tanggal 15 Oktober 2015 sampai dengan 30 November 2015 sebanyak 3 kali pertemuan pada masing-masing kelas eksperimen dan kelas kontrol. Penelitian ini dilaksanakan menggunakan pembelajaran 
Realistic Mathematics Education pada kelas eksperimen dan pada kelas kontrol menggunakan pembelajaran ekspositori, dengan materi pokok "Aritmatika Sosial". Sebelum melakukan penelitian, peneliti menyiapkan Rencana Pelaksanaan Pembelajaran (RPP) sebagai acuan kegiatan belajar (Selengkapnya dapat dilihat pada lampiran 40). Adapun waktu kegiatan pembelajaran di kelas eksperimen yaitu kelas yang menggunakan pembelajaran Realistic Mathematics Education dan kelas kontrol yaitu kelas yang menggunakan pembelajaran ekspositori dapat dilihat pada tabel berikut.

Tabel 1. Waktu Pelaksanaan Penelitian

\begin{tabular}{|c|c|c|c|}
\hline Pertemuan & Kelas Eksperimen & Kelas Kontrol & Keterangan \\
\hline I & 13 November 2015 & 11 November 2015 & KBM \\
\hline II & 14 November 2015 & 16 November 2015 & KBM \\
\hline III & 21 November 2015 & 23 November 2015 & Tes akhir, angket \\
\hline
\end{tabular}

C. Populasi, Sampel, dan Sampling

Suharsimi Arikunto (2010: 173) berpendapat bahwa populasi adalah keseluruhan subjek penelitian. Populasi penelitian ini yaitu seluruh siswa kelas VII SMP N 1 Baki tahun ajaran 2015/2016 yang berjumlah 256 siswa (laki-laki berjumlah 132 siswa dan perempuan berjumlah 124 siswa). Menurut Suharsimi Arikunto (2010: 174), "Sampel adalah sebagian atau wakil populasi yang diteliti”. Dalam penelitian ini sampel yang diambil sebanyak dua kelas yang masing-masing terdiri dari 31 siswa. Sutama (2012: 108) berpendapat bahwa penarikan sampel atau yang lebih dikenal dengan sampling adalah proses penyeleksian sejumlah individu dari populasi yang dilakukan dengan cara tertentu sehingga mampu mewakili populasi. Pengambilan sampel dalam penelitian ini dilakukan dengan teknik simple random sampling.Proses penarikan sampel sebagai berikut.

1. Peneliti mengumpulkan perwakilan kelas untuk melalukan pengundian dalam menentukan pengambilan sampel.

2. Peneliti menyiapkan undian berupa kertas yang dilipat sebanyak 8 buah. Dua buah kertas yang dilipat berisi kalimat "Kelas Eksperimen" dan "Kelas Kontrol” sedangkan sisanya tidak bertuliskan apapun.

3. Perwakilan kelas yang mendapatkan kertas bertuliskan "Kelas Eksperimen" maka kelas dari perwakilan tersebut dijadikan kelas eksperimen dan perwakilan kelas yang mendapatkan kertas bertuliskan "Kelas Kontrol" maka kelasnya dijadikan sebagai kelas kontrol. 
D. Teknik dan Instrumen Pengumpulan Data

1. Teknik Pengumpulan Data

a. Metode tes

b. Metode angket

c. Metode dokumentasi

2. Instrumen Penelitian

a. Tahap penyusunan

1) Tes hasil belajar siswa

2) Angket kemampuan komunikasi matematika siswa

\section{Hasil Penelitian dan Pembahasan}

Pembelajaran pada kelas eksperimen dimulai dengan memberikan masalah kontekstual tentang aritmatika sosial kepada siswa. Masalah tersebut sebagai berikut.

Zulfa menabung di bank sebesar Rp 200.000,--

Setelah 4 tahun, tabungan tesebut menjadi Rp 240.000,-

Berapa suku bunga yang diberikan bank setiap tahunnya?

Gambar 2. Permasalahan Konstekstual

Siswa memahami masalah (soal) kontekstual yang diberikan oleh guru. Berikut salah satu bentuk pemahaman siswa setelah diberikan masalah (soal).

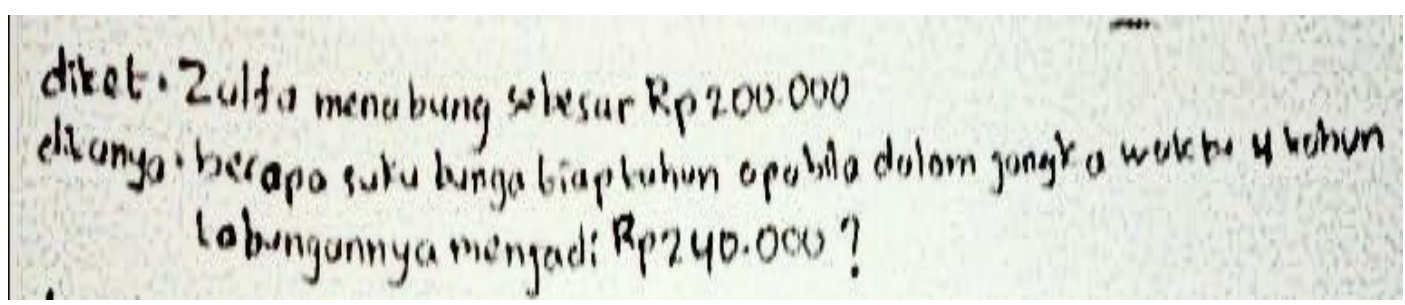

Gambar. 3. Pemahaman Siswa

Berdasarkan Gambar 3, siswa menunjukkan apa yang diketahui dari soal dan apa yang ditanyakan dari soal dengan bentuk lain. Risma Amalia (2014: 141) mengemukakan bahwa siswa dikatakan paham apabila dapat mengubah informasi yang ada di pikirannya ke dalam bentuk lain yang lebih berarti dan bisa menyampaikan informasi tersebut kepada temannya sehingga dapat dipahami juga oleh temannya. Hal ini berarti bahwa siswa yang paham tentang masalah yang diberikan membantu teman yang belum paham menjadi paham. Jika siswa yang belum paham kurang puas, maka guru memberi petunjuk seperlunya tentang masalah tersebut yaitu apa yang diketahui? Data apa saja yang ada dalam masalah tersebut? Apa yang ditanyakan dari masalah tersebut? 
Setelah siswa memahami permasalahan yang diberikan, siswa menyelesaikan masalah tersebut secara individual. Berikut tampilan penyelesaian masalah oleh siswa.

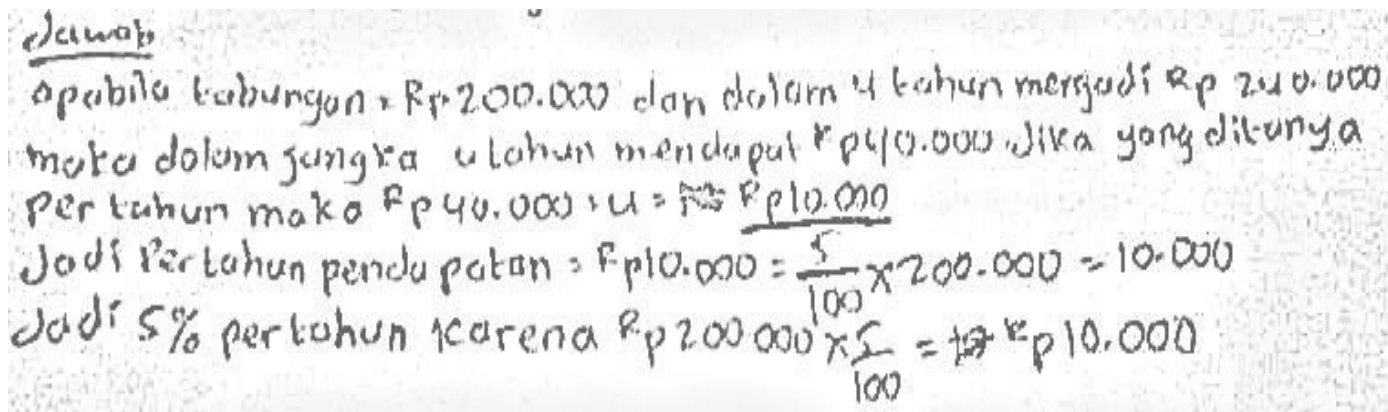

Gambar. 4. Penyelesaian Masalah Secara Individu

Penyelesaian masalah secara individu bertujuan agar siswa menemukan konsep matematika dengan cara mereka sendiri-sendiri sehingga siswa tidak mudah melupakan masalah yang diberikan. Hal ini sesuai dengan pendapat Nida Jarmita dan Hazami (2013) mengenai keunggulan RME yaitu siswa membangun sendiri pengetahuannya sehingga tidak mudah melupakan materi yang diajarkan. Guru membentuk kelompok dan meminta kelompok tersebut bekerja sama mendiskusikan penyelesaian masalah yang telah diselesaikan secara individual. Berikut hasil dari diskusi kelompok.

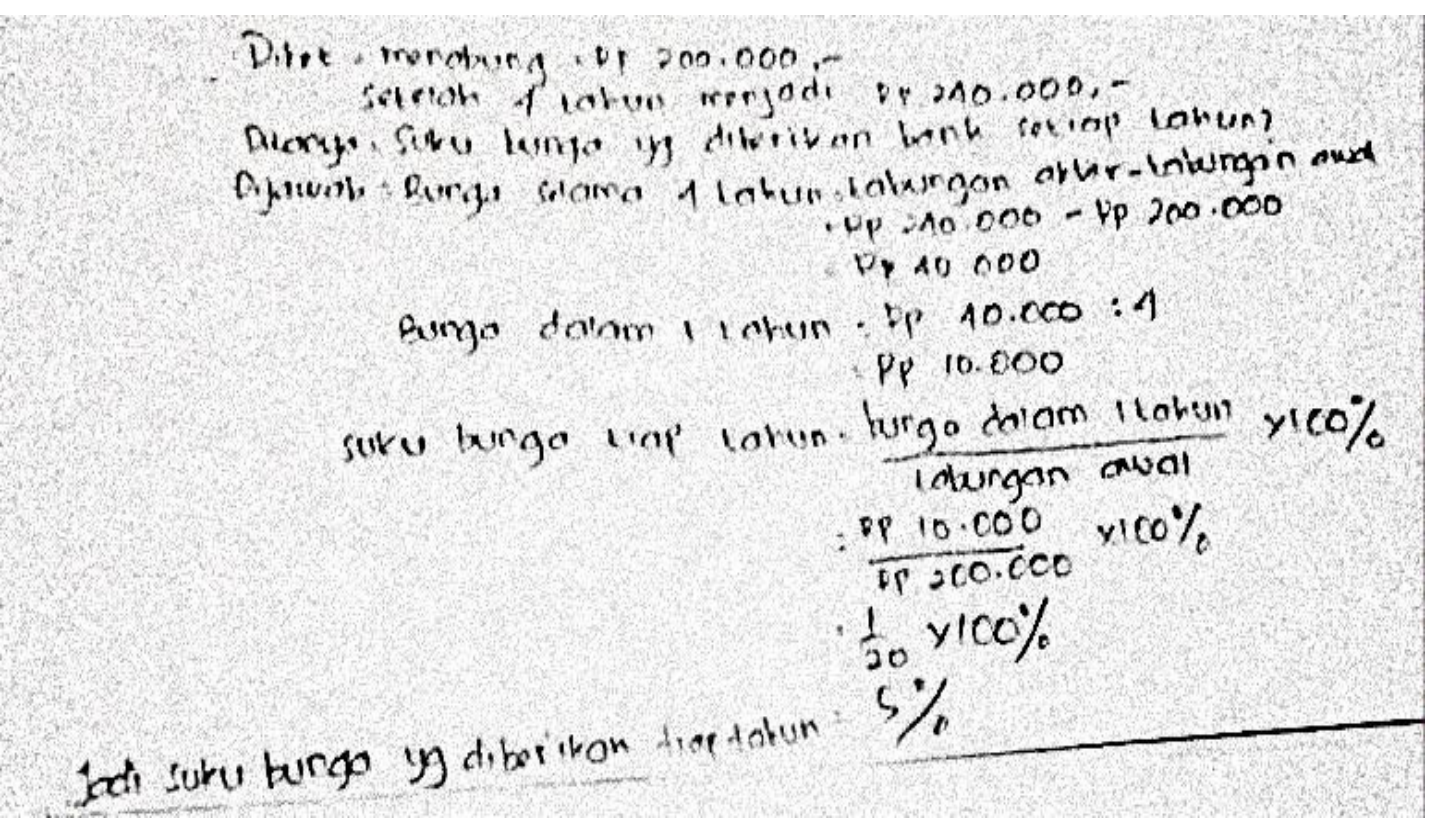

Gambar. 5. Penyelesaian Masalah Secara Kelompok

Dalam berdiskusi, siswa bertukar pendapat mengenai penyelesaian dari masalah yang diberikan. Siswa mengemukan gagasan dan alasan dari penyelesaian masalah yang telah dikerjakan secara individu. Selain itu, siswa juga berlatih dalam menghargai pendapat temannya. Guru bertindak sebagai fasilitator dan moderator yang membimbing 
siswa dalam berdiskusi. Setelah berdiskusi, guru menunjuk perwakilan kelompok untuk mengutarakan jawaban dan alasannya di depan kelas baik lisan maupun tulisan. Pada tahap ini, muncul karakteristik RME yaitu penggunaan ide atau konstribusi siswa dan interaksi antara siswa dengan siswa, guru dengan siswa, dan siswa dengan sumber belajar (Murdani Rahma Johar dan Turmudi: 2013). Selanjutnya guru mengarahkan siswa untuk menarik kesimpulan tentang konsep matematika terkait masalah konstekstual tentang aritmatika sosial yang baru diselesaikan. Berikut salah satu kesimpulan siswa terkait masalah yang diberikan.

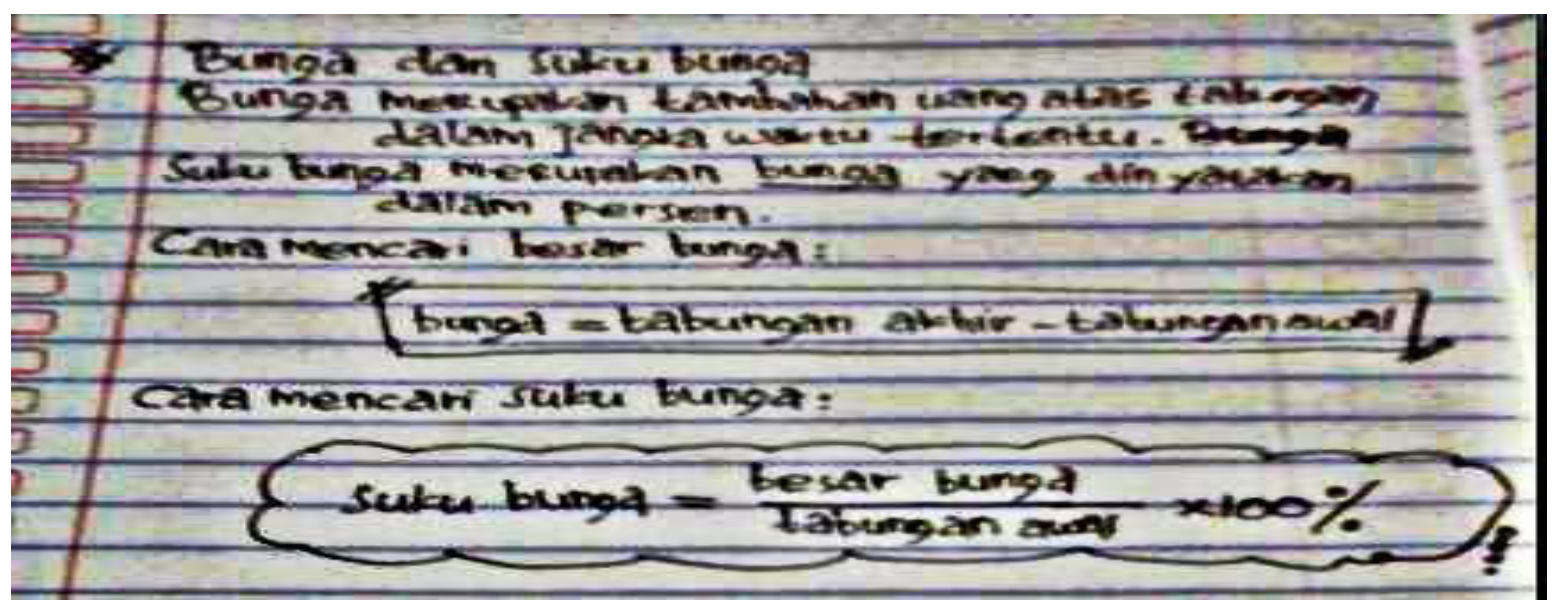

Gambar 6. Kesimpulan yang Dibuat Siswa

Pada tahap terakhir ini, terdapat karakteristik RME yaitu adanya interaksi antar siswa dengan guru dan konstribusi siswa. Hal ini penting dalam Realistic Mathematics Education karena berguna untuk mencapai bentuk pengetahuan matematika formal dari bentuk-bentuk pengetahuan matematika informal yang ditemukan sendiri oleh siswa (Murdani Rahma Johar dan Turmudi: 2013). Pembelajaran pada kelas kontrol menggunakan pendekatan ekspositori. Guru menulis konsep matematika di papan tulis, menjelaskan konsep, memberi contoh, siswa bertanya, guru memberikan soal latihan, siswa mengerjakan dan guru memberikan penilaian dari pekerjaan siswa. Hal ini sesuai dengan karakteristik ekspositori yang dikemukakan Lusia Ari Sumirat (2014) yaitu guru menjelaskan pembelajaran matematika dengan mengungkapkan rumus-rumus dan dalildalil matematika terlebih dahulu, pemberian contoh, siswa diberi kesempatan bertanya, siswa berlatih dengan soal-soal yang disedakan, dan guru memberi penilaian dari hasil kerja siswa tersebut.

Hasil uji normalitas hasil belajar yaitu Lhitung $=0,082280198<\mathrm{L}_{\alpha} ; \mathrm{n}=0,112522$. Hasil uji ini memutuskan bahwa $\mathrm{H}_{0}$ tidak ditolak yang artinya sampel berasal dari populasi yang berdistribusi normal. Hasil uji normalitas kemampuan komunikasi 
matematika diperoleh Lhitung $=0,045747304<\mathrm{L}_{\alpha ; \mathrm{n}}=0,112522$. Hasil uji ini memutuskan bahwa $\mathrm{H}_{0}$ tidak ditolak yang artinya sampel berasal dari populasi yang berdistribusi normal. Oleh karena itu, dapat diasumsikan bahwa sampel yang digunakan dalam penelitian ini mewakili populasi keseluruhan. Hasil uji homogenitas hasil belajar yaitu $\chi^{2}$ hitung $=0,217325528<\chi^{2}$ tabel $=3,841$. Hasil uji ini memutuskan bahwa $\mathrm{H}_{0}$ tidak ditolak yang artinya data hasil belajar kelas eksperimen dan kelas kontrol berasal dari populasi yang homogen. Hasil uji homogenitas kemampuan komunikasi matematika diperoleh $\chi^{2}$ hitung $\quad=0,522161526<\chi^{2}$ tabel $=3,841$. Hasil uji ini memutuskan bahwa $\mathrm{H}_{0}$ tidak ditolak yang artinya data kemampuan komunikasi matematika kelas eksperimen dan kelas kontrol berasal dari populasi yang homogen. Oleh karena itu, dapat diasumsikan bahwa varian dari populasi yang digunakan adalah sama. Hasil analisis variansi dua jalan dengan taraf signifikansi $\alpha=0,05$ disajikan dalam Tabel 4.13. Hasil uji hipotesis pertama diperoleh $\mathrm{F}_{\mathrm{Obs}}=5,573185>\mathrm{F}_{\alpha}=4,01$; maka $\mathrm{H}_{0}$ ditolak, artinya ada pengaruh pembelajaran matematika terhadap hasil belajar. Untuk itu, dilakukan uji komparasi rerata antar baris untuk menentukan bagian yang berpengaruh terhadap hasil belajar. Berdasarkan Tabel 4.14 diperoleh rerata marginal dari pembelajaran matematika berbasis Realistic Mathematics Education sebesar 79,64516 lebih tinggi dari pada rerata marginal pembelajaran ekspositori sebesar 73,64516. Oleh karena itu, penggunaan pembelajaran matematika berbasis Realistic Mathematics Education lebih baik dari pada pembelajaran ekspositori dalam meningkatkan hasil belajar.

Hasil penelitian tersebut sesuai dengan hasil penelitian Zahara dan Abdul Hamid K (2013) yang menyimpulkan bahwa hasil belajar matematika siswa dengan menggunakan pembelajaran matematika realistik lebih tinggi dari hasil belajar siswa dengan pembelajaran langsung. Hal ini bermakna bahwa pembelajaran matematika berbasis Realistic Mathematics Education dapat menyebabkan hasil belajar menjadi lebih baik sehingga dapat disimpulkan pembelajaran matematika berbasis Realistic Mathematics Education berkonstribusi terhadap hasil belajar. Hasil uji hipotesis kedua diperoleh $\mathrm{F}_{\text {obs }}=15,95437>\mathrm{F}_{\alpha}=3,16$; maka $\mathrm{H}_{0}$ ditolak, artinya ada pengaruh kemampuan komunikasi matematika terhadap hasil belajar. Untuk itu, dilakukan uji komparasi antar kolom untuk menentukan bagian mana saja yang berpengaruh terhadap hasil belajar. Berdasarkan Tabel diatas, pada uji komparasi antar kolom antara kemampuan komunikasi matematika kategori tinggi dan sedang diperoleh hasil F.1-.2=10,49716 dengan keputusan 
$\mathrm{H}_{0}$ ditolak. Hal ini berarti rerata yang diperoleh dari kemampuan komunikasi matematika kategori tinggi berbeda secara signifikan dengan rerata yang diperoleh dari kemampuan komunikasi matematika kategori sedang. Perbedaan yang terjadi dikarenakan rerata untuk kemampuan komunikasi matematika kategori tinggi yaitu 83,61905 lebih tinggi dibandingkan dengan rerata kemampuan komunikasi matematika kategori sedang sebesar 78,63636 sesuai dengan Tabel 4.14. Oleh karena itu, hasil belajar ditinjau dari kemampuan komunikasi matematika kategori tinggi lebih baik dari pada hasil belajar ditinjau dari kemampuan komunikasi matematika kategori sedang. Hasil uji komparasi antar kolom antara kemampuan komunikasi matematika kategori tinggi dan rendah diperoleh hasil F.1-.3 = 116,926 dengan keputusan $\mathrm{H}_{0}$ ditolak. Hal ini berarti rerata yang diperoleh dari kemampuan komunikasi matematika kategori tinggi berbeda secara signifikan dengan rerata yang diperoleh dari kemampuan komunikasi matematika kategori rendah. Perbedaan yang terjadi dikarenakan rerata untuk kemampuan komunikasi matematika kategori tinggi yaitu 83,61905 lebih tinggi dibandingkan dengan rerata kemampuan komunikasi matematika kategori rendah sebesar 66,63158 sesuai dengan Tabel. Oleh karena itu, hasil belajar ditinjau dari kemampuan komunikasi matematika kategori tinggi lebih baik dari pada hasil belajar ditinjau dari kemampuan komunikasi matematika kategori rendah.

Hasil uji komparasi antar kolom antara kemampuan komunikasi matematika kategori sedang dan rendah diperoleh hasil F.2-.3 = 116,926 dengan keputusan $\mathrm{H}_{0}$ ditolak. Hal ini berarti rerata yang diperoleh dari kemampuan komunikasi matematika kategori sedang berbeda secara signifikan dengan rerata yang diperoleh dari kemampuan komunikasi matematika kategori rendah. Perbedaan yang terjadi dikarenakan rerata untuk kemampuan komunikasi matematika kategori sedang lebih sedang yaitu 78,63636 lebih tinggi dibandingkan dengan rerata kemampuan komunikasi matematika kategori rendah sebesar 66,63158 sesuai dengan Tabel. Oleh karena itu, hasil belajar ditinjau dari kemampuan komunikasi matematika kategori sedang lebih baik dari pada hasil belajar ditinjau dari kemampuan komunikasi matematika kategori rendah. Hasil penelitian tersebut sesuai dengan hasil penelitian A. Astuti dan Leonard (2015) yang menyimpulkan bahwa semakin tinggi kemampuan komunikasi matematika semakin tinggi pula prestasi belajar matematika. Hal ini bermakna bahwa kemampuan komunikasi matematika yang dimiliki siswa dapat menyebabkan hasil belajar menjadi lebih baik. Siswa yang memiliki kemampuan komunikasi matematika kategori tinggi mendapatkan hasil 
belajar yang lebih baik dari pada siswa dengan kemampuan komunikasi sedang dan rendah. Oleh karena itu dapat disimpulkan kemampuan komunikasi matematika berkonstribusi terhadap hasil belajar. Hasil uji hipotesis ketiga diperoleh $\mathrm{F}_{\mathrm{obs}}=3,445566>\mathrm{F}_{\alpha}=3,16 ;$ maka $\mathrm{H}_{0}$ ditolak, artinya ada pengaruh pembelajaran matematika terhadap hasil belajar ditinjau dari kemampuan komunikasi matematika. Untuk itu, dilakukan uji komparasi antar sel pada kolom dan baris yang sama untuk menentukan bagian mana saja yang berpengaruh terhadap hasil belajar. Hasil uji komparasi rerara antar pembelajaran matematika ditinjau dari kemampuan komunikasi matematika kategori tinggi, diperoleh F11-21 = 5,196243 dengan keputusan H0 tidak ditolak. Pada variabel kemampuan komunikasi matematika kategori tinggi, tidak ada pembelajaran matematika yang secara signifikan mempunyai rerata berbeda yang dapat berpengaruh terhadap hasil belajar. Hal ini berarti karakteristik antara pembelajaran matematika berbasis Realistic Mathematics Education dan pembelajaran ekspositori untuk kemampuan komunikasi matematika kategori tinggi sama dengan karaktersitik rerata marginal pembelajaran matematika. Berdasarkan Tabel diatas, rerata marginal pembelajaran matematika berbasis Realistic Mathematics Education yaitu 79,64516 lebih tinggi dari pada rerata marginal pembelajaran ekspositori sebesar 73,64516 yang menunjukkan bahwa pembelajaran matematika berbasis Realistic Mathematics Education lebih baik dari pada pembelajaran ekspositori. Hasil ini sesuai dengan hasil penelitian Novi Yosheva dkk (2013) menyimpulkan pembelajaran matematika yang menggunakan Realistic Mathematics Education dapat meningkatkan kemampuan kognitif siswa. Hal ini bermakna bahwa penggunaan pembelajaran matematika berbasis Realistic Mathematics Education kepada siswa dapat meningkatkan hasil belajar. Oleh kerena itu, pada kemampuan komunikasi matematika kategori tinggi, hasil belajar ditinjau dari pembelajaran matematika berbasis Realistic Mathematics Education lebih baik dari pada hasil belajar ditinjau dari pembelajaran ekspositori.

Hasil uji komparasi rerara antar pembelajaran matematika ditinjau dari kemampuan komunikasi matematika kategori sedang, diperoleh F11-21 = 5,196243 dengan keputusan Ho tidak ditolak sesuai Tabel 4.16. Pada variabel kemampuan komunikasi matematika kategori sedang, tidak ada pembelajaran matematika yang secara signifikan mempunyai rerata berbeda yang dapat berpengaruh terhadap hasil belajar. Hal ini berarti karakteristik antara pembelajaran matematika berbasis Realistic Mathematics Education dan pembelajaran ekspositori untuk kemampuan komunikasi matematika kategori 
sedang sama dengan karaktersitik rerata marginal pembelajaran matematika.

Berdasarkan Tabel, rerata marginal pembelajaran matematika berbasis Realistic Mathematics Education yaitu 79,64516 lebih tinggi dari pada rerata marginal pembelajaran ekspositori sebesar 73,64516 yang menunjukkan bahwa pembelajaran matematika berbasis Realistic Mathematics Education lebih baik dari pada pembelajaran ekspositori. Hasil penelitian Hirza dkk (2014) menyimpulkan Realistic Mathematics Education dapat meningkatkan kemampuan intuisi siswa daripada pembelajaran konvensional. Hal ini bermakna bahwa pembelajaran matematika berbasis Realistic Mathematics Education yang diterapkan kepada siswa dapat meningkatkan kemampuan intuisinya sehingga dapat berdampak pada hasil belajar. Oleh karena itu, pada kemampuan komunikasi matematika kategori sedang, hasil belajar ditinjau dari pembelajaran matematika berbasis Realistic Mathematics Education juga lebih baik dari pada hasil belajar ditinjau dari pembelajaran ekspositori. Hasil uji komparasi rerara antar pembelajaran matematika ditinjau dari kemampuan komunikasi matematika kategori rendah, diperoleh F11-21 = 5,196243 dengan keputusan $\mathrm{H}_{0}$ tidak ditolak sesuai Tabel 4.16. Pada variabel kemampuan komunikasi matematika kategori rendah, tidak ada pembelajaran matematika yang secara signifikan mempunyai rerata berbeda yang dapat berpengaruh terhadap hasil belajar. Hal ini berarti karakteristik antara pembelajaran matematika berbasis Realistic Mathematics Education dan pembelajaran ekspositori untuk kemampuan komunikasi matematika kategori rendah sama dengan karaktersitik rerata marginal pembelajaran matematika. Berdasarkan Tabel, rerata marginal pembelajaran matematika berbasis Realistic Mathematics Education yaitu 79,64516 lebih tinggi dari pada rerata marginal pembelajaran ekspositori sebesar 73,64516 yang menunjukkan bahwa pembelajaran matematika berbasis Realistic Mathematics Education lebih baik dari pada pembelajaran ekspositori. Hasil penelitian V. Arsyathamby dan Cut Morina Zubainur (2014) menyimpulkan IRME membuat siswa aktif membangun pemahaman mereka. Hal ini bermakna bahwa penerapan pembelajaran matematika berbasis Realistic Mathematics Education menyebabkan siswa aktif membangun pemahaman mereka sehingga berdampak pada hasil belajar. Oleh karena itu, pada kemampuan komunikasi matematika kategori rendah, hasil belajar ditinjau dari pembelajaran matematika berbasis Realistic Mathematics Education juga lebih baik dari pada hasil belajar ditinjau dari pembelajaran ekspositori. Hasil uji komparasi rerata pada kolom yang sama memberikan arti bahwa hasil belajar dengan menggunakan pembelajaran matematika berbasis Realistic Mathematics Education lebih baik dari pada hasil belajar dengan menggunakan pembelajaran ekspositori ditinjau 
dari kemampuan komunikasi matematika siswa. Hasil uji komparasi rerara antara kemampuan komunikasi matematika kategori tinggi dan sedang ditinjau dari pembelajaran matematika berbasis Realistic Mathematics Education, diperoleh F11-12 = 7,430324 dengan keputusan $\mathrm{H}_{0}$ tidak ditolak sesuai Tabel 4.17. Ditinjau dari pembelajaran matematika berbasis Realistic Mathematics Education, rerata yang diperoleh dari kemampuan komunikasi matematika kategori tinggi tidak berbeda secara signifikan dengan rerata yang diperoleh kemampuan komunikasi matematika kategori sedang. Hal ini berarti karakteristik antara kemampuan komunikasi matematika kategori tinggi dan sedang sama dengan karakteristik rerata marginal kemampuan komunikasi matematika. Berdasarkan Tabel, rerata marginal kemampuan komunikasi matematika kategori tinggi yaitu 83,61905 lebih tinggi dari pada rerata marginal kemampuan komunikasi matematika kategori sedang sebesar 78,63636 yang menunjukkan bahwa kemampuan komunikasi matematika kategori tinggi lebih baik dari pada kemampuan komunikasi matematika kategori sedang. Hasil penelitian Mohammad Asikin dan Iwan Junaedi (2013) menyimpulkan Realistic Mathematics Education dapat menumbuhkan kemampuan komunikasi matematika. Hal ini bermakna bahwa dengan menerapkan pembelajaran matematika berbasis Realistic Mathematics Education dapat meningkatkan kemampuan komunikasi matematika sehingga berpengaruh terhadap hasil belajar. Oleh karena itu, pada pembelajaran matematika berbasis Realistic mathematics Education, kemampuan komunikasi matematika kategori tinggi lebih baik dari pada kemampuan komunikasi matematika kategori sedang terhadap hasil belajar. Hasil uji komparasi rerara antara kemampuan komunikasi matematika kategori tinggi dan rendah ditinjau dari pembelajaran matematika berbasis Realistic Mathematics Education, diperoleh $\mathrm{F} 11-13=13,24616$ dengan keputusan $\mathrm{H}_{0}$ ditolak sesuai Tabel 4.17. Hal ini berarti ditinjau dari pembelajaran Realistic Mathematics Education, rerata yang diperoleh dari kemampuan komunikasi matematika kategori tinggi berbeda secara signifikan dengan rerata yang diperoleh dari kemampuan komunikasi matematika kategori rendah. Perbedaan yang terjadi dikarenakan pada pembelajaran Realistic Mathematics Education, rerata untuk kemampuan komunikasi matematika kategori tinggi yaitu 88,18182 lebih tinggi dibandingkan dengan rerata kemampuan komunikasi matematika kategori rendah sebesar 72,4444 sesuai dengan Tabel 4.14. Oleh karena itu, hasil belajar ditinjau dari kemampuan komunikasi matematika kategori tinggi lebih baik dari pada hasil belajar ditinjau dari kemampuan komunikasi matematika kategori rendah. 
Hasil uji komparasi rerara antara kemampuan komunikasi matematika kategori sedang dan rendah ditinjau dari pembelajaran matematika berbasis Realistic Mathematics Education, diperoleh F12-13 = 1,109962 dengan keputusan $\mathrm{H}_{0}$ tidak ditolak sesuai Tabel 4.17. Ditinjau dari pembelajaran matematika berbasis Realistic Mathematics Education, rerata yang diperoleh dari kemampuan komunikasi matematika kategori sedang tidak berbeda secara signifikan dengan rerata yang diperoleh kemampuan komunikasi matematika kategori rendah. Hal ini berarti karakteristik antara kemampuan komunikasi matematika kategori sedang dan rendah sama dengan karakteristik rerata marginal kemampuan komunikasi matematika. Berdasarkan Tabel, rerata marginal kemampuan komunikasi matematika kategori sedang yaitu 78,63636 lebih tinggi dari pada rerata marginal kemampuan komunikasi matematika kategori rendah sebesar 66,63158 yang menunjukkan bahwa kemampuan komunikasi matematika kategori sedang lebih baik dari pada kemampuan komunikasi matematika kategori rendah. Hasil penelitian Siti Chotimah (2014) menyimpulkan peningkatan kemampuan komunikasi matematika dengan menggunakan Realistic Mathematics Education lebih baik dari pada dengan menggunakan cara biasa atau konvensional. Hal ini bermakna bahwa penggunaan pembelajaran matematika berbasis Realistic Mathematics Education meningkatkan kemampuan komunikasi matematika yang lebih baik dibanding cara biasa sehingga berpengaruh terhadap hasil belajar. Oleh karena itu, pada pembelajaran matematika berbasis Realistic mathematics Education, kemampuan komunikasi matematika kategori sedang lebih baik dari pada kemampuan komunikasi matematika kategori rendah terhadap hasil belajar. Pembelajaran matematika berbasis Realistic Mathematics Education pada siswa yang memiliki kemampuan komunikasi matematika kategori sedang memiliki hasil belajar yang lebih baik dari siswa dengan kemampuan komunikasi matematika kategori rendah pada kelas yang sama. Uji komparasi rerata antar sel pada baris yang sama memberikan arti bahwa ditinjau dari pembelajaran matematika berbasis Realistic Mathematics Education, siswa yang memiliki kemampuan komunikasi matematika kategori tinggi memperoleh hasil belajar yang lebih baik dari pada siswa dengan kemampuan komunikasi matematika kategori sedang dan rendah. Berdasarkan uji komparasi rerata antar sel pada kolom dan baris yang sama dapat disimpulkan bahwa interaksi pembelajaran matematika berbasis Realistic Mathematics Education dan kemampuan komunikasi matematika berkonstribusi terhadap hasil belajar. Dengan demikian, dukungan kemampuan komunikasi matematika yaitu kemampuan yang dimiliki siswa dalam mempelajari matematika 
sehingga siswa dapat menghubungkan informasi matematika dan menjelaskan baik lisan maupun tulisan serta prinsip Realistic Mathematics Education yang memberi kesempatan kepada siswa untuk mengkonstruksikan pengetahuannya berdampak pada hasil belajar yang lebih baik. Oleh karena itu, hasil belajar yang diperoleh siswa selain dipengaruhi oleh pembelajaran berbasis Realistic Mathematics Education dan kemampuan komunikasi matematika juga dipengaruhi oleh interaksi di antara keduanya.

\section{Simpulan}

Pembelajaran matematika berbasis Realistic Mathematics Education dimulai dengan memberi masalah kontekstual kepada siswa. Siswa memahami masalah tersebut dan apabila siswa belum memahaminya maka dibantu oleh teman lain yang paham. Selanjutnya siswa menyelesaikan masalah tersebut secara individual yang bertujuan agar siswa menemukan konsep matematika dengan cara mereka sendiri-sendiri dengan bimbingan dari guru. Siswa yang telah menyelesaikan masalah membandingkan jawabannya dengan kelompok yang dibentuk guru. Selain membandingkan jawaban, di dalam kelompok siswa saling bertukar pikiran tentang jawaban dari masalah yang diberikan. Setelah beberapa siswa mengutarakan jawaban dan alasannya, guru mengarahkan siswa untuk menarik kesimpulan tentang konsep matematika terkait masalah konstekstual tentang aritmatika sosial yang baru diselesaikan, adalah sebagai berikut:

1. Pada taraf signifikansi 0,05 hasil belajar dengan menggunakan pembelajaran matematika berbasis Realistic Mathematics Education lebih baik dari pada pembelajaran ekspositori. Oleh karena itu, dapat disimpulkan bahwa penggunaan pembelajaran matematika berbasis Realistic Mathematics Education berkonstribusi terhadap hasil belajar.

2. Pada taraf signifikansi 0,05 hasil belajar ditinjau dari kemampuan komunikasi matematika kategori tinggi lebih baik dari pada hasil belajar ditinjau dari kemampuan komunikasi matematika sedang dan rendah.

3. Pada taraf signifikansi 0,05 hasil belajar dengan menggunakan pembelajaran matematika berbasis Realistic Mathematics Education lebih baik dari pada hasil belajar dengan menggunakan pembelajaran ekspositori ditinjau dari kemampuan komunikasi matematika siswa. Ditinjau dari pembelajaran matematika berbasis Realistic Mathematics Education, siswa yang memiliki kemampuan komunikasi matematika kategori tinggi memperoleh hasil belajar yang lebih baik dari pada siswa dengan kemampuan komunikasi matematika kategori sedang dan rendah. Oleh karena 
itu, dapat disimpulkan bahwa interaksi pembelajaran matematika berbasis Realistic Mathematics Education dan kemampuan komunikasi matematika berkonstribusi terhadap hasil belajar.

4. Penelitian yang telah dilakukan menunjukkan bahwa semua hipotesis yang telah dirumuskan menghasilkan terdapat konstribusi antara pembelajaran matematika berbasis Realistic mathematics Education ditinjau dari kemampuan komunikasi matematika siswa terhadap hasil belajar.

\section{Daftar Pustaka}

Abdul Qohar. 2011. "Pengembangan Instrumen Komunikasi Matematis untuk Siswa SMP”. Makalah Disajikan di Seminar Nasional Pendidikan Matematika LSM XIX, pada 16 April 2011, Universitas Negeri Yogyakarta, Yogyakarta. Diakses tanggal 21 Maret $2015 \quad$ (http://eprints.uny.ac.id/6968/1/Makalah\%20Peserta\% 204\%20$\% 20$ Abd.\%20 Qohar2.pdf).

Amalia, Risma. (2014). "Meningkatkan Kemampuan Pemahaman Matematik Siswa SMP Swasta di Kota Cimahi dengan Menggunakan Metode Pembelajaran Improve". Prosiding Seminar Nasional Matematika dan Pendidikan Matematika, 2: 140148. Diakses tanggal 19 Oktober 2015 (http://publikasi. stkipsiliwangi.ac.id/files/2014/01/Prosiding-Semnas-STKIP-2014.pdf).

Arikunto, Suharsimi. 2010. "Prosedur Penelitian Suatu Pendekatan Praktik". Jakarta: Rineka Cipta.

Arsaythamby, V. dan Cut Morina Zubainur. 2014.'How A Realistic Mathematics Educational Approach Affect Students' Activities In Primary Schools?". ProcediaSocial and Behavioral Sciences, 159: 309-313. Diakses tanggal 3 Oktober 2015 (http://ac.els-cdn.com/S1877042814065082/1-s2.0-S187704281 4065082main.pdf? tid=cb735c22-7734-11e5-95f3-00000aab0f27\&acdnat=14 45350614 _Od24cdc $5 d 8 a 3241$ b ecaad $7 b 52321 c f c c)$.

Asikin, Mohammad. dan Iwan Junaedi. 2013. "Kemampuan Komunikasi Matematika Siswa SMP Dalam Setting Pembelajaran RME (Realistic Mathematics Education)". Unnes Journal of Mathematics Education Research 2(1): 203- 207. Diakses tanggal 7 Oktober 2015 (http://journal.unnes.ac.id/sju/index.php/ ujmer/ article/view /1483/1440).

Astuti, A., dan Leonard. 2015. "Peran Kemampuan Komunikasi Matematika Terhadap Prestasi Belajar Matematika Siswa". Jurnal Formatif 2(2): 102-110. Diakses tanggal 21 Januari $2016 \quad$ (http://journal.lppmunindra.ac.id/index.php/Formatif/ article/viewFile/91/88).

Bowo, A. N. A. (2014). Small Group Discussion Berbasis Reading Guide untuk Peningkatan Keaktifan dan Hasil Belajar PKn Siswa MTs. Academy of Education Journal, 5(2).

Budiyono. 2009. "Statistika Untuk Penelitian”. Surakarta: Sebelas Maret University 
Press.

Chotimah, Siti. 2014. "Upaya Meningkatkan Kemampuan Komunikasi Matematik Siswa SMP di Kota Bandung Dengan Pendekatan Realistic Mathematics EducationnPada Siswa SMP di Kota Bandung". Prosiding Seminar Nasional Matematika dan Pendidikan Matematika, 2: 133-139. Diakses tanggal 19 Oktober 2015 (http://publikasi. stkip siliwangi.ac.id/files/2014/01/Prosiding-Semnas-STKIP2014.pdf).

Peraturan Menteri Pendidikan Nasional Nomor 22 tahun 2006 Tentang Standar Isi Untuk Satuan Pendidikan Dasar dan Menengah. 2006. Jakarta: Departemen Pendidikan Nasional.

Peraturan Menteri Pendidikan dan Kebudayaan Nomor 58 Tahun 2014 Tentang Kurikulum 2013 Sekolah Menengah Pertama/Madrasah Tsanawiyah. 2014. Jakarta: Departemen pendidikan Nasional.

Prianto, Heri. 2013. "Peningkatan Hasil Belajar Matematika Melalui Pendekatan Matematika Realistik (PMR) Siswa Kelas II-A MI Alhikam Geger Madiun Tahun Pelajaran 2012/2013”. Jurnal Ilmiah Pendidikan, 1(1): 91-104. Diakses tanggal 4 Oktober 2015 (stkipdrnugroho.ac.id/up-pdf/heriprianto.pdf).

Siregar, Salamat. 2013.”Meningkatkan Pemahaman dan Hasil Belajar Siswa Pada Mata Pelajaran Matematika Dengan Menggunakan Software Graphmatica". Edumatica, 3(1): 55-63. Diakses tanggal 9 Oktober 2015 (http://onlinejournal.unja.ac.id/index.php/edumatica/article/view/1410/909).

Sumirat, Lusia Ari. 2014. "Efektifitas Strategi Pembelajaran Kooperatif Tipe Think- TalkWrite (TTW) terhadap Kemampuan Komunikasi dan Disposisi Matematis Siswa". Jurnal Pendidikan dan Keguruan, 1(2): 21-29. Diakses tanggal 24 Januari 2016 (http://pasca.ut.ac.id/journal/index.php/JPK/article/viewFile/56/56)

Sutama. 2012. Metode Penelitian Pendidikan Kuantitatif, Kualitatif, PTK, R\&D. Kartasura: Fairuz Media

Undang-undang Republik Indonesia Nomor 20 Tahun 2003 Tentang Sistem Pendidikan Nasional. 2003. Jakarta: Departemen Pendidikan Nasional.

Webb, David C., Henk van der Kooij, dan Monica R. Geist. 2011. "Design Research in the Netherlands: Introducing Logarithms Using Realistic Mathemathics Education". Journal of Mathematics Education at Teachers College, 2(6): 47-52. Diakses tanggal 3 Oktober 2015 (http://journals.tc-library.org/index.php/ matheducation larticle/viewFile/639/405).

Zahara dan Abdul Hamid K. 2013. "Strategi Pembelajaran dan Sikap Matematika Terhadap Hasil Belajar Matematika”. Jurnal Teknologi Matematika, 6(2): 244- 258. Diakses tanggal 9 Oktober 2015 (http://digilib.unimed.ac.id/publik/ UNIMEDArticle-29515-9-Zahara-Abdul\%20Hamid\%20K\%2020244-258.pdf). 